\title{
EVALUASI PENATAUSAHAAN BARANG MILIK DAERAH MENURUT PP NO. 27 TAHUN 2014 PADA BADAN PENGELOLA KEUANGAN DAN ASET DAERAH KOTA MANADO
}

\author{
Priscila T. Supit ${ }^{1}$, Jantje J. Tinangon ${ }^{2}$, Lidia M. Mawikere ${ }^{3}$ \\ ${ }^{1,2,3}$ Fakultas Ekonomi dan Bisnis, Jurusan Akuntansi, Universitas Sam Ratulangi, Jl.Kampus Bahu, Manado \\ 95115, Indonesia \\ E-mail: priscila_supit@yahoo.com
}

\begin{abstract}
Administration is the activity of managing assets that includes bookkeeping, inventorying and the reporting of region's asset according to the terms and condition that applies. Administration has an important role in policy making, as all policy will be better and more suitable with accurate and valid data that comes from the act of administration. The main objective of this research is to find out whether the managing of regionals assets towards the Financial and Asset management Agency of the City of Manado is according to Government's Regulation No. 27 Year 2014. The method of analysis that is used on this research is the qualitative descriptive method. The result of this research shows that the administration of regional's assets towards the Financial and Asset management Agency of the City of Manado has been implemented but not according to Government's Regulation No. 27 Year 2014. The cause of the reporting mechanism failing to follow the Government's regulation No. 27 Year 2014 is due to the failure of Asset management Agency of the City of Manado not having a Goods Authority. Therefore the Asset management Agency of the City of Manado needs to create the Department of Regional Technical Implementation so that the head of the department will be the Goods Authority and will be in charge of creating the semester and yearly reports.
\end{abstract}

Keywords: Administration, Region's Asset According

\section{PENDAHULUAN}

Pengelolaan Barang Milik Negara/Daerah (BMN/D) telah dituntut untuk meningkatkan komitmen dalam pengelolaannya baik dalam rangka penatausahaan, pengamanan, perkuatan, maupun pengamanan terhadap seluruh aset yang cukup besar. Pemerintah daerah memiliki hak dan kewenangan yang luas untuk menggunakan sumbersumber keuangan yang dimilikinya sesuai dengan kebutuhan dan aspirasi masyarakat yang berkembang di daerah bahwa pemerintah daerah dapat menggunakan sumber-sumber keuangan yang dimilikinya sekehendaknya, tanpa arah dan tujuan yang jelas. Kewenangan tersebut berupa amanah yang harus dipertanggung jawabkan secara akuntabel dan transparan baik kepada masyarakat maupun kepada Pemerintah Pusat yang telah Membagikan dana perimbangan kepada seluruh daerah (Muatiarohma, 2014)

Aset merupakan sarana pendukung jalannya sebuah operasi suatu organisasi yang memegang peranan penting khususnya aset tetap. Aset tetap digunakan dalam kegiatan operasional dan tidak dimaksudkan untuk dijual dalam rangka kegiatan normal perusahaan. Aset tetap pemda sebagai salah satu pos neraca, yang mempengaruhi Laporan Realisasi Anggaran melalui pos beban penyusutan atau beban lain merupakan pos yang memerlukan suatu pengelolan dan kebijakan yang sesuai dengan peraturan pemerintah Republik Indonesia Nomor 24 tahun 2005 Tentang Standar Pengelolaan Akuntansi Pemerintah baik pengakuan, pengukuran, maupun ketelitian dalam pencatatan akuntansinya (Hilmah, 2014). 
Peraturan Pemerintah Nomor 27 Tahun 2014 menyatakan penatausahaan adalah rangkaian kegiatan yang meliputi pembukuan, inventarisasi, dan pelaporan barang milik daerah sesuai dengan ketentuan yang berlaku. Dalam penatausahaan ini termasuk didalamnya melaksanakan tugas dan fungsi akuntansi barang milik negara/daerah. Penatausahaan barang milik negara/daerah dalam rangka mewujudkan tertib administrasi termasuk menyusun Laporan BMN/D yang akan digunakan sebagai bahan penyusunan neraca pemerintah pusat. Sedangkan penatausahaan BMN/D dalam rangka mendukung terwujudnya tertib pengelolaan BMN/D adalah menyediakan data agar pelaksanaan pengelolaan BMN/D dapat sesuai dengan asas fungsional, kepastian hukum, transparansi dan keterbukaan, efisiensi, akuntabilitas, dan kepastian nilai (Febrianty, 2016).

Penatausahaan barang milik negara/daerah meliputi pembukuan, inventarisasi, dan pelaporan. Barang milik negara/daerah yang berada dibawah penguasaan pengguna barang/kuasa pengguna barang harus dibukukan melalui proses pencatatan dalam Daftar Barang Kuasa Pengguna oleh kuasa pengguna barang, Daftar Barang Pengguna oleh pengguna barang dan Daftar Barang Milik Negara/Daerah oleh pengelola barang. Proses inventarisasi, baik berupa pendataan, pencatatan, dan pelaporan hasil pendataan barang milik negara/daerah merupakan bagian dari penatausahaan. Hasil dari proses pembukuan dan inventarisasi diperlukan dalam melaksanakan proses pelaporan barang milik negara/daerah yang dilakukan oleh kuasa pengguna barang, pengguna barang, dan pengelola barang. Hasil penatausahaan barang milik negara/daerah digunakan dalam rangka penyusunan neraca pemerintah pusat/daerah setiap tahun. Dari latar belakang masalah yang telah diuraikan, maka penulis merumuskan masalah yang akan dibahas yaitu apakah penatausahaan barang milik daerah pada Badan Pengelola Keuangan dan Aset Daerah Kota Manado sudah berjalan sesuai dengan Peraturan Pemerintah Nomor 27 Tahun 2014? Tujuan penelitian untuk mengetahui penatausahaan barang milik daerah pada Badan Pengelola Keuangan dan Aset Daerah Kota Manado khususnya dalam mekanisme pelaporannya sudah berjalan sesuai dengan Peraturan Pemerintah Nomor 27 Tahun 2014 ?

\section{TINJAUAN PUSTAKA}

\subsection{Pengertian Akuntansi}

Weygandt, Kimmel \& Kieso (2011 :7) Akuntansi adalah sistem informasi yang mengidentifikasi, mencatat dan mengkomunikasikan peristiwa ekonomi dari suatu organisasi kepada pihak yang memiliki kepentingan. Akuntansi adalah suatu aktivitas jasa yang terdiri dari mencatat, mengklasifikasikan suatu informasi keuangan yang dibutuhkan oleh pihakpihak tertentu untuk pengambilan keputusan. (V. Wiratna Sujarweni, 2015 dalam bukunya yang berjudul "Akuntansi Sektor Publik"). "Accounting was defined as the art of recording, classifying and summarizing in a meaningful way and in monetary value, the actions that are least of a financial nature and the interpretation of these results" (Zybery and Rova, 2014).

Menurut Winston Pontoh (2013 :2) akuntansi pada dasarnya akan menghasilkan informasi dari sebuah sistem akuntansi yang ada di dalam sebuah entitas atau organisasi bisnis yang disebut dengan informasi akuntansi yang akan dimanfaatkan oleh pengguna seperti masyarakat umum, masyarakat intelektual (termasuk didalamnya mahasiswa atau peneliti) dan para pengambil keputusan bisnis dalam organisasi. Pengertian Akuntansi menurut Warren, Reeve dan Duchac (2011:3), Akuntansi adalah sebuah sistem informasi yang memberikan laporan kepada pengguna mengenai kegiatan ekonomi dan kondisi dari sebuah bisnis. Akuntansi secara resmi diartikan sebagai sebuah sistem yang menghasilkan "informasi kuantitatif, mengenai dasar keuangan, tentang entitas ekonomi yang diharapkan berguna untuk mengambil keputusan ekonomi”. 


\subsection{Akuntansi Sektor Publik}

Akuntansi Sektor Publik didefinisikan sebagai mekanisme teknik dan analisis akuntansi yang diterapkan pada pengelolaan dana masyarakat di lembaga-lembaga tinggi Negara dan departemen-departemen di bawahnya, pemerintah daerah, BUMN, BUMD, LSM, dan yayasan sosial, maupun proyek-proyek kerjasama sektor publik dan swasta. Mardiasmo (2012 :37) dalam pengertian umum yang khususnya bagi dunia akuntansi dinegara-negara maju organisasi sektor publik terbagi dalam tiga kelompok besar yaitu :

1. Pemerintah Pusat, yang terdiri dari departeman dan badan-badan di bawah pemerintah eksekutif.

2. Industri atau perusahaan untuk kepentingan publik atau masyarakat luas.

3. Pemerintah Daerah, bagi tingkat propinsi maupun kabupaten/kota.

Sektor publik adalah semua yang berhubungan dengan kepentingan publik dan tentang penyediaan barang dan jasa yang ditujukan untuk publik, dibayarkan melalui pajak dan pendapatan negara lainnya yang sudah diatur dalam hukum.

\subsection{Akuntansi Pemerintahan}

Akuntansi pemerintahan adalah akuntansi yang bersangkutan dengan bidang keuangan negara, dari anggaran sampai dengan pelaksanaan dan pelaporannya, termasuk segala pengaruh yang ditimbulkan (Sujarweni dalam bukunya berjudul Akuntansi Sektor Publik). Menurut Mursyidi (2012 :1), Akuntansi Pemerintahan (governmental accounting) banyak menyatakan teminologi lama dan bergeser ke istilah akuntansi sektor publik. Akuntansi pemerintahan adalah mekanisme akuntansi yang memproses transaksi keuangan yang berkaitan dengan pengelolaan keuangan negara baik tingkat pusat maupun tingkat daerah.

Sadeli (2015:6) Menyatakan akuntansi pemerintahan termasuk pula akuntansi lembaga-lembaga nonprofit atau institusional accounting, mengkhususkan pada masalah pencatatan dan pelaporan transaksi dari unit-unit pemerintah dan organisasi nonprofit lainnya, seperti: mesjid, lembaga amal, yayasan, rumah sakit, dan lembaga-lembaga pendidikan.

Nordiawan et.al (2011:4), menyatakan bahwa akuntansi pemerintahan mengkhususkan dalam pencatatan dan pelaporan transaksi-transaksi yang terjadi di badan pemerintah. Akuntan pemerintah menyediakan laporan akuntansi tentang aspek kepengurusan dari administrasi keuangan negara. Selain itu, bidang ini meliputi pengendalian atas peng eluaran melalui anggaran negara, termasuk kesesuaiannya dengan UU yang berlaku.

\subsection{Barang Milik Daerah}

Peraturan Pemerintah Republik Indonesia Nomor 27 Tahun 2014 pasal 1 menjelaskan

1. Barang Milik Negara adalah semua barang yang dibeli atau diperoleh atas beban Anggaran Pendapatan dan Belanja Negara atau berasal dari perolehan lainnya yang sah.

2. Barang Milik Daerah adalah semua barang yang dibeli atau diperoleh atas beban Anggaran Pendapatan dan Belanja Daerah atau berasal dari perolehan lainnya yang sah.

Peraturan Menteri Dalam Negeri Nomor 27 Tahun 2014 Pasal 2 menyatakan bahwa:

(1) Barang Milik Negara/Daerah meliputi:

a. Barang yang dibeli atau diperoleh atas beban Anggaran Pendapatan dan Belanja Negara/Daerah; dan

b. Barang yang berasal dari perolehan lainnya yang sah. meliputi:

1. Barang yang diperoleh dari hibah/sumbangan atau yang sejenis;

2. Barang yang diperoleh sebagai pelaksanaan dari perjanjian/kontrak;

3. Barang yang diperoleh sesuai dengan ketentuan peraturan perundang-undangan; atau

4. Barang yang diperoleh berdasarkan putusan pengadilan yang telah berkekuatan hukum tetap. 
Menurut M. Yusuf (2010:13) Barang Milik Daerah merupakan salah satu unsur penting dalam rangka penyelenggaraan pemerintah dan pelayanan kepada masyarakat, oleh karena itu harus dikelola dengan baik dan benar sehingga akan terwujud ppengelolaan barang daerah yang transparan, efisien, akuntabel dan adanya kepastian nilai yang dapat berfungsi sesuai dengan tugas pokok dan fungsi dari pemerintah daerah.

\subsection{Penatausahaan Barang Milik Daerah}

Penatausahaan berdasarkan Permendagri No. 17 Tahun 2007 Pasal 4 merupakan proses melakukan pembukuan, inventarisasi dan pelaporan barang milik daerah sehingga apabila penatausahaan tidak sesuai dengan prosedur yang ada maka akan mengakibatkan laporan aset Negara/daerah tidak sinkron dengan laporan keuangan.

Menurut Peraturan Pemerintah No. 14 tahun 2014 penatausahaan barang milik Negara/Daerah terdiri dari pembukuan, inventarisasi dan pelaporan.

\subsubsection{Pembukuan}

Pembukuan adalah proses pencatatan barang milik daerah kedalam daftar barang pengguna dan kedalam kartu inventaris barang serta dalam daftar barang milik daerah. Pengguna/kuasa pengguna barang wajib melakukan pendaftaran dan pencatatan barang milik daerah ke dalam Daftar Barang Pengguna (DBP)/Daftar Barang Kuasa Pengguna (DBKP)

\subsubsection{Investarisasi}

Inventarisasi merupakan kegiatan atau tindakan untuk melakukan perhitungan, pengurusan, penyelenggaraan, pengaturan, pencatatan data dan pelaporan barang milik daerah dalam unit pemakaian.

\subsubsection{Pelaporan}

Pelaporan barang milik daerah yang dilakukan pengguna barang disampaikan setiap semesteran, tahunan dan 5 (lima) tahunan kepada pengelola. Yang dimaksud dengan pelaporan adalah proses penyusunan laporan barang semester dan setiap tahun setelah dilakukan inventarisasi dan pencatatan. Pengguna menyampaikan laporan pengguna barang semesteran, tahunan, dan 5 (lima) tahunan kepada Kepala Daerah melalui pengelola. Sementara Pembantu Pengelola menghimpun seluruh laporan pengguna barang semesteran, tahunan dan 5 (lima) tahunan dari masing-masing SKPD, jumlah maupun nilai serta dibuat rekapitulasinya.

\subsection{Asas Pengelolaan Barang Milik Daerah}

Pengelolaan Barang Milik Daerah harus dilakukan dengan memperhatikan Asas Pengelolaan Barang Milik Daerah, yaitu :

1. Asas Fungsional, yaitu pengambilan keputusan dan pemecahan masalah di bidang pengelolaan barang milik daerah yang dilaksanakan oleh Kuasa Pengguna Barang, Pengguna Barang, Pengelola Barang, dan Kepala Daerah sesuai fungsi, wewenang dan tanggung jawab masing-masing;

2. Asas Kepastian Hukum, yaitu pengelolaan barang milik daerah harus dilaksanakan berdasarkan hukum dan peraturan perundang-undangan;

3. Asas Transparansi, yaitu penyelengaraan pengelolaan barang milik daerah harus transparan terhadap hak masyarakat dalam memperoleh informasi yang benar;

4. Asas Efisiensi, yaitu pengelolaan barang milik daerah diarahkan agar barang milik daerah digunakan sesuai batasan-batasan standar kebutuhan yang diperlukan dalam rangka menunjang penyelenggaraan tugas pokok dan fungsi pemerintahan secara optimal;

5. Asas Akuntabilitas, yaitu setiap kegiatan pengelolaan barang milik daerah harus dapat dipertanggungjawabkan kepada rakyat; 
Asas Kepastian Nilai, yaitu pengelolaan barang milik daerah harus didukung adanya ketepatan jumlah dan nilai barang dalam rangka optimalisasi pemanfaatan dan pemindahtanganan barang milik daerah.

\section{METODE PENELITIAN}

\subsection{Jenis \& Sumber Data}

Jenis Penelitian yang digunakan adalah jenis penelitian yang bersifat studi deskriptif guna menjelaskan apakah penatausahaan Barang Milik Daerah khususnya mengenai mekanisme pelaporan Barang Milik daerah pada Badan Pengelola Keuangan dan Aset Daerah Kota Manado sudah berjalan sesuai dengan Peraturan Pemerintah Nomor 27 Tahun 2014.

Dalam penelitian ini sumber data yang digunakan adalah data sekunder, yaitu Penatausahaan pengelolaan Barang Milik Daerah pada Badan Pengelola Keuangan dan Aset Daerah Kota Manado. Sumber data yang digunakan dalam penelitian ini adalah studi pustaka, yaitu pengumpulan data sekunder dari buku-buku literatur, jurnal-jurnal, catatan atau informasi dari pihak lain sehubungan dengan masalah yang dibahas. Selain itu juga melalui dokumentasi.

\subsection{Metode Analisis Data}

Metode analisis data dilakukan dengan metode deskriptif kualitatif. Dengan metode analisis deskriptif kualitatif peneliti akan mengkaji, menelaah semua data yang diperoleh dari Badan Pengelolah Keuangan dan Aset Daerah Kota Manado untuk mendapatkan gambaran yang jelas tentang bagaimana penatausahaan barang milik daerah khususnya mengenai mekanisme pelaporan barang milik daerah. Kemudian data yang diperoleh dari bidang barang milik daerah pada Badan Pengelola Keuangan dan Barang Milik Daerah Kota Manado dipelajari dan diolah. Setelah hasil telah didapat maka akan dibandingkan dengan teori dan Peraturan Pemerintah No. 27 Tahun 2014 sehingga dapat ditarik kesimpulan yang dapat menjawab rumusan masalah dalam penelitian ini.

\section{HASIL PENELITIAN DAN PEMBAHASAN \\ 4.1 Hasil Penelitian}

\section{1) Penatausahaan Barang Milik Daerah}

Berdasarkan hasil wawancara pada pegawai Badan Pengelola Keuangan dan Aset Daerah Kota Manado bahwa penatausahaan untuk setiap barang milik daerah yang telah ditetapkan status penggunaannya, dilakukan oleh setiap kepala SKPD. Setiap kepala SKPD (melalui penyimpan/pengurus barang) wajib melakukan penatausahaan BMD yang ada pada pengguna masing-masing. Penatausahaan BMD meliputi:

Pembukuan

Pembukuan adalah pencatatan barang yang digunakan pada pengguna barang, agar barang yang digunakan tercatat dengan baik. Pemerintah kota Manado melalui Badan Pengelola Keuangan dan Aset Daerah Kota Manado telah melakukan pencatatan barang milik daerah sesuai dengan spesifikasinya. Berdasarkan hasil observasi dokumen pada Badan Pengelola Keuangan dan Aset Daerah Kota Manado terdapat Kartu Inventaris Barang yang terdiri dari:

a) Kartu Inventaris Barang (KIB) A: Tanah

b) Kartu Inventaris Barang (KIB) B: Peralatan dan Mesin

c) Kartu Inventaris Barang (KIB) C: Gedung dan Bangunan

d) Kartu Inventaris Barang (KIB) D: Jalan, Irigasi dan Jaringan

e) Kartu Inventaris Barang (KIB) E: Aset Tetap Lainnya

f) Kartu Inventaris Barang (KIB) F: Konstruksi Dalam Pengerjaan Inventarisasi 
Setelah melakukan pembukuan, dilakukan Inventarisasi barang. Inventarisasi dimaksudkan untuk melakukan perhitungan, pengurusan, pengaturan, dan pencatatan data barang milik daerah pada unit pemakai. Dari kegiatan ini, disusun Buku Inventaris yang menunjukan semua barang yang dimiliki baik yang bergerak maupun tidak bergerak. Data dari buku inventaris direkap oleh pembantu pengelola agar supaya pengelolaan barang milik daerah berjalan dengan baik sesuai dengan aturan yang berlaku.

Hasil dari inventarisasi digunakan untuk memutakhirkan data KIB (KIB A, B, C, D, E dan F). Selanjutnya KIB tersebut akan dikompilasi menjadi buku inventaris. Buku Inventaris memberikan informasi semua kekayaan daerah yang bersifat kebendaan, baik yang bergerak maupun yang tidak bergerak, data barang (lokasi, jenis/merk type, jumlah, ukuran, harga, tahun pembelian, asal barang, keadaan barang dan sebagainya). Adanya buku inventaris yang lengkap, teratur dan berkelanjutan mempunyai fungsi dan peran yang sangat penting untuk pengendalian, pemanfaatan, pengamanan dan pengawasan setiap barang; pemanfaatan setiap barang secara maksimal sesuai dengan tujuan dan fungsinya masing-masing; serta menunjang pelaksanaan tugas pemerintah. Inventarisasi harus diadministrasikan dengan tepat dan lengkap untuk dapat menyajikan informasi yang valid dan relevan. Informasi tersebut merupakan faktor penting dalam pengambilan keputusan yang berhubungan dengan kekayaan daerah. Suatu informasi yang diperoleh dari data yang tidak valid dan relevan dapat mengakibatkan pengambilan keputusan yang salah.

\section{- Pelaporan}

Proses selanjutnya yaitu pelaporan, dimana dalam laporan ini terdapat laporan tentang penggunaan barang beserta jumlah serta rekapitulasinya. Kepala SKPD selaku pengguna barang menyampaikan laporan penggunaan barang semesteran, tahunan dan 5 tahunan kepada Kepala Daerah melalui sekertaris daerah. Pembantu pengelola menghimpun seluruh Laporan Penggunaan Barang semesteran, tahunan dan 5 tahunan dari masing-masing SKPD, baik jumlah maupun nilainya dan membuat rekapitulasinya. Hasil rekapitulasi ini yang menjadi bahan pembuatan Neraca Daerah.

\section{2) Pelaporan Barang Milik Daerah}

Peraturan Pemerintah Nomor 27 Tahun 2014 khususnya Pasal 87 tentang Pelaporan, menyebutkan yang pertama bahwa Kuasa Pengguna Barang harus menyusun Laporan Barang Kuasa Pengguna Semesteran dan Tahunan sebagai bahan untuk menyusun neraca satuan kerja untuk disampaikan kepada Pengguna Barang. Kedua, bahwa Pengguna Barang menghimpun Laporan Barang Kuasa Pengguna Semesteran dan Tahunan sebagaimana dimaksud pada ayat 1 atau yang pertama sebagai bahan penyusunan Laporan Barang Pengguna Semesteran dan Tahunan. Ketiga, Laporan Barang Pengguna sebagaimana dimaksud pada ayat 2 atau yang kedua digunakan sebagai bahan untuk menyusun neraca Kementrian/Lembaga/satuan kerja perangkat daerah untuk disampaikan kepada Pengelola Barang.

Berdasarkan hasil wawancara maka dapat diketahui bahwa Badan Pengelola Keuangan dan Aset Daerah Kota Manado belum melaksanakan pelaporan barang milik daerah sebagaimana diamanatkan Pasal 27 ayat 1 yang menyebutkan "Kuasa Pengguna Barang harus menyusun Laporan Barang Kuasa Pengguna Semesteran dan Tahunan sebagai bahan untuk menyusun neraca satuan kerja untuk disampaikan kepada Pengguna Barang”. Hal ini disebabkan karena BPKAD belum membentuk UPTD (Unit Pelaksanaan Teknis Daerah) atau Unit Kerja yang ada di BPKAD Kota Manado. Kepala UPTD merupakan kuasa pengguna barang yang dalam pengelolaan barang milik daerah berada dibawah pengguna barang atau dalam hal ini berada dibawah Kepala BPKAD Kota Manado. 


\subsection{Pembahasan}

\section{1) Penatausahaan Barang Milik Daerah}

Berdasarkan hasil penelitian yang diperoleh bahwa penatausahaan barang milik daerah merupakan kegiatan pengadministrasian yang meliputi pembukuan, inventarisasi, dan pelaporan. Pengguna barang harus melakukan pendaftaran dan pencatatan BMN/D kedalam Daftar Barang Kuasa Pengguna Barang (DBKP)/Daftar Barang Pengguna (DBP) menurut penggolongan dan kodifikasi barang. Inventarisasi BMN/D adalah peritungan ulang atas BMN/D dengan membandingkan catatan dengan fisik BMN/D yang harus dilakukan oleh Pengguna Barang sekurang-kurangnya sekali dalam lima tahun. Pelaporan BMN/D dilakukan Pengguna Barang/Kuasa Pengguna Barang dengan menyusun Laporan Barang Pengguna Semesteran (LBPS) dan Laporan Barang Pengguna Tahunan (LBPT). Pengelola Barang harus menyusun Laporan Barang Milik Negara Daerah LBMN/D berupa tanah dan/atau bangunan secara semesteran dan tahunan. Laporan Barang Milik Negara/Daerah digunakan untuk menyusun neraca pemerintah pusat/daerah.

Undang-Undang yang dipakai pada Badan Pengelola Keuangan dan Aset Daerah Kota Manado adalah Peraturan Pemerintah No. 27 Tahun 2014.

Dalam pelaksanaan penatausahaan barang milik daerah pada Badan Pengelola Keuangan dan Aset Daerah Kota Manado juga dilakukan inventarisasi dan pencatatan terhadap aset daerah setiap 6 bulan dan akhir tahun dan dirumuskan menjadi Laporan Barang Milik Daerah (LBMD) sehingga dapat diketahui bertambah atau berkurangnya aset di setiap periode berdasarkan Laporan Barang Pengguna Semesteran (LBPS) dan Laporan Barang Pengguna Tahunan (LBPT) dari Badan Pengelola Keuangan dan Aset Daerah Kota Manado.

Berdasarkan hasil penelitian yang diperoleh bahwa penatausahaan barang milik daerah sesuai dengan Peraturan Pemerintah Nomor 27 Tahun 2014 dimana Badan Pengelola Keuangan dan Aset Daerah Kota Manado telah menjalankan penatausahaan barang milik daerah mulai dari tahap pembukuan, inventarisasi dan pelaporan.

Pembukuan

Dalam pelaksanaan pembukuan barang milik daerah, Badan Pengelola Keuangan dan Aset Daerah Kota Manado sudah melaksanakan pembukuan yang merupakan proses pencatatan barang milik daerah kedalam daftar barang pengguna dan kedalam kartu inventaris serta dalam daftar barang milik daerah. Sebelum melakukan pencatatan barang, terlebih dahulu dilakukan penggolongan dan kodefikasi barang/aset tetap daerah.

Inventarisasi

Dari hasil pelaksanaan inventarisasi barang milik daerah pada Badan Pengelola Keuangan dan Aset Daerah Kota Manado, dapat diketahui aktiva tetap yang benar-benar dimiliki oleh Pemerintah Daerah, kemudian dilakukan penilaiannya sesuai dengan kebijakan akuntansi Pemerintah Daerah. Hasil penilaian aktiva tetap merupakan saldo awal kelompok aset tetap dalam neraca atau merupakan dukungan atas saldo aset tetap dalam neraca. Dalam perencanaan pengadaan barang, perencanaan pemeliharaan, dan proses penghapusan inventaris yang telah memenuhi persyaratan penghapusan tentu membutuhkan informasi dengan kualitas data yang memadai. Untuk kepentingan penyajian informasi yang berkualitas diperlukan berbagai bentuk formulir atau dokumen inventaris. Kegiatan inventarisasi merupakan kegiatan untuk melakukan perhitungan, pengurusan, penyelenggaraan, pengaturan, pencatatan data dan pelaporan barang milik daerah dalam unit pemakaian. Dari hasil inventarisasi, dapat diketahui aktiva tetap yang benar-benar dimiliki oleh Pemerintah Daerah, kemudian dilakukan penilaiannya sesuai dengan kebijakan akuntansi Pemerintah Daerah. Hasil penilaian aktiva tetap merupakan saldo awal kelompok aset tetap dalam neraca atau merupakan dukungan atas saldo aset tetap dalam neraca. Pelaksanaan inventarisasi pada Badan Pengelola Keuangan dan Aset Daerah Kota Manado sudah dilaksanakan sesuai dengan ketentuan yang berlaku. Hal ini dapat dilihat dari bukti- 
bukti pelaksanaan inventarisasi seperti adanya dokumen pencatatan, misalnya Buku Induk Inventaris, Buku Inventaris, KIB, KIR. Selain itu adanya dokumen pelaporan seperti Daftar Rekapitulasi Inventaris dan Daftar Mutasi Barang.

Dalam kegiatan inventarisasi barang juga terdapat Sensus Barang/Aset Daerah. Proses sensus barang dilakukan oleh pengelola dan pengguna barang milik daerah setiap 5 (lima) tahun sekali untuk menyusun buku inventaris dan buku induk inventaris beserta rekapitulasi barang milik pemerintah daerah. Dengan demikian dapat diketahui kembali bahwa kegiatan penatausahaan tidak hanya terdiri dari pembukuan, inventarisasi dan pelaporan saja tetapi termasuk kegiatan sensus barang milik daerah yang merupakan kegiatan inventarisasi yang dilaksanakan tiap 5 (lima) tahun sekali. Tujuan sensus barang daerah adalah untuk mendapatkan data barang negara dan daerah yang dikuasai oleh daerah yang dibukukan dan selanjutnya meningkatkan daya guna dan hasil guna serta memberikan jaminan pengamanan dan penghematan terhadap setiap penggunaan barang milik pemerintah.

\section{- $\quad$ Pelaporan}

Pelaporan barang milik daerah yang dilakukan pengguna barang disampaikan setiap semesteran, tahunan dan 5 (lima) tahunan kepada pengelola. Pengguna menyampaikan laporan pengguna barang semesteran, tahunan, dan 5 (lima) tahunan kepada Kepala Daerah melalui pengelola. Sementara Pembantu Pengelola menghimpun seluruh laporan pengguna barang semesteran, tahunan dan 5 (lima) tahunan dari masing-masing SKPD, jumlah maupun nilai serta dibuat rekapitulasinya.

Pencatatan barang milik daerah pada Badan Pengelola Keuangan dan Aset Daerah Kota Manado menghasilkan daftar yang disebut daftar barang kuasa pengguna (DBKP) dan daftar barang pengguna (DBP). Selanjutnya, dilakukan pelaporan secara berjenjang berdasarkan informasi yang terdapat dalam daftar barang pengguna dan daftar barang kuasa pengguna.

\section{2) Pelaporan Barang Milik Daerah}

Pelaporan dalam Peraturan Pemerintah Nomor 27 yaitu aset/BMD dikelompokkan dalam Kartu Inventaris Barang A - Kartu Inventaris Barang F. Untuk pemerintah kota Manado telah melaporkan aset/BMD disamping menggunakan Peraturan Pemerintah Nomor 27 dalam 6 kelompok sesuai dengan kelompok Kartu Inventaris Barang juga membuat laporan BMD dengan menambahkan laporan aset lain-lain dan aset tak berwujud. Hal ini dilakukan dalam rangka mengakomodir ketentuan yang berkaitan dengan laporan konsolidasi laporan keuangan pemerintah Kota Manado. Dimana laporan aset itu merupakan bagian dari laporan keuangan sebab jika hanya mencantumkan 6 Kartu Inventaris Barang saja dalam neraca nantinya laporan keuangan akan kehilangan saji khusus untuk nilai aset tak berwujud dan aset lain-lain. Sementara aset tak berwujud dan aset lain-lain merupakan aset/BMD yang dikelola BPKAD. Dalam membuat laporan BMD, BPKAD mengambil rekap atau total kartu inventaris barang dan buku inventaris, jika melebar berarti juga mengambil Daftar BMD yang dicantumkan dineraca. Laporan merupakan nilai rekap sama dengan neraca/nilai tetap. Mekanisme dalam membuat laporan BMD yaitu misalnya dalam salah satu Kartu Inventaris Barang yang akan dibuat hanya totalnya saja. Jadi, kaitan kartu inventaris barang dengan laporan BMD yaitu bahwa nilai yang dicantumkan dalam kartu inventaris barang hanya totalnya saja.

Berdasarkan hasil penelitian dimana pelaksanaan pelaporan barang milik daerah yang dilaksanakan pada BPKAD Kota Manado telah dijalankan namun masih belum optimal menurut Peraturan Pemerintah Nomor 27 Tahun 2014 karena belum dilaksanakan sesuai dengan yang tertera dalam Pasal 87 Ayat 1 yaitu BPKAD belum mempunyai Kuasa Pengguna Barang dan untuk mempunyai Kuasa Pengguna Barang BPKAD harus membentuk UPTD (Unit Pelaksanaan Teknis Daerah) atau Unit Kerja sehingga dari situ nanti akan ada Kepala UPTD yang nantinya merupakan Kuasa Pengguna Barang, namun ternyata BPKAD 
belum membentuk UPTD tersebut sehingga BPKAD belum memiliki Kuasa Pengguna Barang.

Jadi pelaksanaan penatausahaan Barang Milik Daerah yang berada di bawah pengelolaan Satuan Kerja (Satker) Badan Pengelola Keuangan dan Aset Daerah Kota Manado telah dilaksanakan namun dalam mekanisme pelaporan belum sesuai dengan Peraturan Pemerintah Nomor 27 Tahun 2014 tentang Pengelolaan Barang Milik Daerah.

\section{KESIMPULAN DAN SARAN}

\section{Kesimpulan}

Dari hasil Penelitian yang dilakukan, beserta data yang didapat. Maka penulis dapat menarik kesimpulan dalam studi kasus yang dilakukan pada Badan Pengelola Keuangan dan Aset Daerah Kota Manado. Yaitu sebagai berikut:

1. Penatausahaan Barang Milik Daerah pada Badan Pengelola Keuangan dan Aset Daerah Kota Manado sudah dilaksanakan sesuai dengan Peraturan Pemerintah Nomor 27 tahun 2014 yaitu pembukuan, inventarisasi dan pelaporan.

2. Pembukuan Barang Milik Daerah yang berada di bawah pengelolaan Satuan Kerja (Satker) Badan Pengelola Keuangan dan Aset Daerah Kota Manado sudah dilakukan sesuai dengan peraturan yang berlaku, yaitu Peraturan Pemerintah Nomor 27 Tahun 2014 tentang Pengelolaan Barang Milik Daerah dibuktikan dengan data yang ada dalam daftar barang pengguna, kartu inventaris barang serta dalam daftar barang milik daerah.

3. Inventarisasi Barang Milik Daerah pada Satker Badan Pengelola Keuangan dan Aset Daerah Kota Manado sudah dilakukan dengan benar yang dilaksanakan bersama dengan kegiatan sensus barang/aset daerah yang juga merupakan kegiatan inventarisasi dalam penatausahaan dan dapat dibuktikan dengan alur dan data yang ada mengenai inventarisasi barang milik daerah.

4. Pelaporan Barang Milik Daerah belum berjalan optimal karena belum seluruhnya dijalankan sesuai dengan Peraturan Pemerintah Nomor 27 Tahun 2014 yaitu harus adanya kuasa pengguna barang yang nantinya akan menyusun laporan barang kuasa pengguna semesteran dan tahunan sebagai bahan untuk menyusun neraca satuan kerja untuk disampaikan kepada pengguna barang dan Badan Pengelola Keuangan dan Aset Daerah Kota Manado belum membentuk UPTD (Unit Pelaksanaan Teknis Daerah) atau Unit Kerja sehingga belum memiliki kuasa pengguna barang, karena kepala UPTD tersebut yang merupakan kuasa pengguna barang.

\section{Saran}

Berdasarkan hasil penelitian dan kesimpulan yang ada, maka ada beberapa saran yang ingin penulis sampaikan kepada Badan Pengelola Keuangan dan Aset Daerah Kota Manado yaitu :

1. Bagi Badan Pengelola Keuangan dan Aset Daerah Kota Manado agar kegiatan penatausahaan aset daerah khususnya dalam mekanisme pelaporan harus dilaksanakan sesuai dengan peraturan yang berlaku. Yaitu dengan membentuk UPTD (Unit Pelaksanaan Teknis Daerah) atau Unit Kerja sehingga Kepala UPTD tersebut nantinya yang akan menjadi kuasa pengguna barang dan akan menyusun laporan kuasa pengguna barang semesteran dan tahunan. Selain itu, harus mengkhususkan satu bidang untuk penatausahaan barang milik daerah, sehingga pelaksanaan penatausahaan aset daerah dapat dilaksanakan dengan semaksimal mungkin, karena penatausahaan aset tersebut sangat diperlukan untuk penyusunan laporan aset daerah dan pengklasifikasian aset daerah. 
2. Pelaksanaan yang sudah ditetapkan agar dilaksanakan lebih baik lagi untuk kedepannya sehingga dalam penatausahaan barang milik daerah seluruh pegawai sudah memahami bagaimana menjalankan pelaksanaannya dengan baik dan benar.

3. Sebaiknya Badan Pengelola Keuangan dan Aset Daerah Kota Manado untuk lebih meningkatkan lagi pelatihan/diklat untuk menambah wawasan, kreatifitas dan kinerja pegawai sehingga tujuan instansi akan mudah untuk dicapai.

\section{DAFTAR PUSTAKA}

Febrianty Sukma. 2016. Analisis Pengaruh Penatausahaan Aset tetap Terhadap Kualitas Laporan Keuangan Pemerintah Daerah Kabupaten Kubu Raya Jurnal Ekonomi Manajemen Vol. 10 No. 1, Januari 2016.

Hilmah Fairoza 2016. Analisis Pelaksanaan Penatausahaan dan Akuntansi Aset tetap pada DPKA Kota Padang. Journal of Applied Finance and Accounting 5(1).

Mardiasmo 1.2011 .Perpajakan Edisi Revisi: Penerbit Andi. Yogyakarta

Mursyidi 2012 "akuntansi pemerintah di Indonesia”. Bandung: Penerbit Refika Aditama.

Muatiarohmah Gina. 2014. Pengaruh Penatausahaan Aset Tetap Terhadap Kewajaran Informasi Keuangan Pada Dinas Daerah Tasikmalaya. Journal of Applied Finance and Accounting 5(1) Diakses pada 21 Januari 2017,110-128.

M. Yusuf. 2013. Langkah Pengelolaan Aset Daerah, Menuju Pengelolaan Keuangan Daerah Terbaik. Salemba Empat. Jakarta.

Nordiawan, Deddi, Iswahyudi Sondi Putra dan Maulidah Rahmawati. 2007. Akuntansi Pemerintahan. Penerbit Salemba Empat. Jakarta.

Pontoh, Winston. 2013 “Akuntansi Konsep dan Aplikasi”. Penerbit Halaman Moeka, Jakarta.

Peraturan Pemerintah Republik Indonesia Nomor 27 Tahun 2014 Tentang Pengelolaan Barang Milik Negara/Daerah.

Peraturan Menteri Dalam Negeri Nomor 17 Tahun 2007 Tentang Pedoman Teknis Pengelolaan Barang Milik Negara.

Sadeli, Lili. 2015. Dasar-dasar Akuntansi. Edisi Pertama. Bumi Aksara, Jakarta.

Sujarweni, Wiratna. 2015. Akuntansi Sektor Publik. Pustaka Baru Press, Yogyakarta.

Warren, Carl S., Reeve, James M. danDuchac, Jonathan. 2011. Accounting Volume 3.Cengage Learning. Singapore.

Weygandt, Jerry J., Kimmel, Paul D., Kieso, Donald E. 2011. Financial Accounting, IFRS Edition. USA: John Wiley \& Sons, Inc.

Zybery, Hirjana, Lindita Rova. 2014. The Role Of The Accountants in the Frame Work Of Modern Technological Developments and Digital Accounting System.Europan Scientific Journal (24) 1857-7431). University Of Gijirokastra, Albania 